\title{
Monetary and financial risks in International relations
}

\author{
Konopleva Julia Alexandrovna \\ Department of Finance and Credit \\ North-Caucasus Federal University \\ Stavropol, Russia \\ ylia-konopleva733@mail.ru \\ Zenchenko Svetlana Vyacheslavovna \\ Department of Finance and Credit \\ North-Caucasus Federal University \\ Stavropol, Russia \\ zen_sveta@mail.ru
}

\author{
Pakova Olga Nikolaevna \\ Department of Finance and Credit \\ North-Caucasus Federal University \\ Stavropol, Russia \\ onpakova@mail.ru \\ Sokolova Alfiya Ahmetovna \\ Department of Finance and Credit \\ North-Caucasus Federal University \\ Stavropol, Russia \\ alfiasocol@rambler.ru
}

\begin{abstract}
- the topical risk management issues in the world financial market are given a closer look in this article. Also, the risk factors are revealed and their classification is given. The risk management model is presented and the risk insurance is examined. Risk assessment methods are studied as well.
\end{abstract}

Keywords—risk types, financial instruments, currency clause, option, futures (contract), forward (contract).

\section{INTRODUCTION}

The modern economic climate shows that more and more countries are becoming international relations parties. The economic development of any country is inextricably linked with international cooperation and interaction based on various international interests such as world commerce, lending, defense, international programs and projects implementation and other forms of interaction [1].

International settlements are at the heart of international cooperation, since they are associated with the accumulation, distribution, redistribution and use of cash and financial assets. International settlements are defined as payment regulations of monetary claims and liabilities, connected with economical, political, scientific, technical and cultural relations among citizens, organizations and different countries [2].

The contribution of international settlements is highly beneficial to the development of the national economy, its competitiveness and significance on the international arena. However, it is worth taking into account that any operations and calculations, including international ones, are developing in conditions of uncertainty. Seeing this, one is unable to give a $100 \%$ guarantee of achieving an intended result.

The market economy keeps developing and it puts at risk any international operations. It also puts the state and other business entities under real pressure to properly assess risks and find the ways to insure them.
The research objective is to study the variety of risks in international monetary and financial transactions.

The goals are as follows:

- To study the causes and factors of risk;

- To study the risk management methods;

- To analyze risk assessment in international transactions;

- $\quad$ To study the standard methods of risk management in the credit market;

- To study the risk insurance methods in the foreign exchange market;

- To study the international hedging methods.

\section{THEORETICAL FRAMEWORKS, METHODOLOGY}

Before characterizing the concept of risk in international monetary and financial relations, it is necessary to define the idea of international relations, their structure and content.

International relations is a combination of various cooperation forms, in numerous spheres, such as political, cultural, legal and economic ones [3].

One way or another, these types of relations are likely to generate certain obligations and monetary demands of the international relations participants. The basis of international relations is the international settlements, i.e. the process of selling and buying goods or services in foreign currency. As a rule, the international settlements cover certain segments of financial market such as credit, currency, gold markets or other derivative financial instruments. Naturally, there is a close interconnection of each segment and international 
settlements, which arise in one market can freely move to another market.

International relations may well be at risk since the market economy is continuously developing. Risk is a situation which involves being exposed to danger [4]. Also, risk could be defined as the unforeseen loss of expected profits, income or property, cash and other resources due to accidental changes in economic conditions as well as unfavorable circumstances [5].

On the other hand, risk might be identified with possible luck. The recent years have shown that the use of different types of insurance in the currency and credit markets has not only allowed one to warn against adverse consequences but also to obtain additional income.

Risk could also characterize the potential money loss, i.e. the money that was invested in securities and other financial assets [6]. Seeing this, risk should be understood not only as the possibility of losses in international transactions, but also as a category which indicates the uncertainty of risk and the follow-up uncertainty of all the participants of transactions.

It is highly important to mark out the risk and chance management concept, which involves both the risk of loss and the chance to gain benefits by one of the counterparties, surely at the expense of another. The management system itself includes this approach and determines the direction of risk management accordingly. It is meant to reduce risks and increase the chance to gain benefits in international monetary and financial transactions. So, while conducting the international operations, it is always necessary to detect possible hazards and factors that can significantly affect the outcome of the transaction.

\section{RESULTS AND DISCUSSION}

To manage risks, it is necessary to differentiate any possible factors and sources of their origin.

Risk factors in international monetary and financial operations are as follows:

A) (the) macro level:

- $\quad$ Economic growth slump

- Economic crunch

- Inflation increase

- Balance payment deterioration

- $\quad$ Public debt increase both external and internal

- International reserves reduction

- Capital flow; financial market instability

- Legislation changes

- $\quad$ Politics

- Country's international rating
B) micro level:

- Counterparty's financial deterioration

- Importer and borrower's insolvency

- $\quad$ Exchange rate instability

- Interest rate fluctuations

- Virtual transactions

- $\quad$ E-banking

- $\quad$ Fraud

- Ghost economy

- Hidden information

- Subjective factors such as trust in the counterparty, participants' irrational behaviour, etc.

The factors presented above require the timely identification and interpretation.

It is self evident that participants in international monetary and financial relations are exposed to various risks. Striking examples of such risks could be financial and commercial risks, the risk of non-return, supply price change, interest rate change, late payment, inaccurate amount of payment, or an overdue date, fraud, illegal actions, currency counterfeiting or document forgery, inflation, a debtor country's international rating decrease, currency and refinancing rate fluctuations, etc. [7].

Therefore entrepreneurs or investors should have full knowledge of all possible types of risks that may arise and have a negative impact on their financial status. Naturally, it is impossible to eliminate all risks. However, it is more than possible to manage them by figuring out how to diminish their consequences [8].

\section{RISK CLASSIFICATIONS}

Risks are diverse and it is impossible to insure all of them. There are more than 220 types of risks. The basic ones are displayed in the table presented below.

In view of the recent political events, special attention should be paid to the country risk. The country risk arises from counterparty's actions in international transactions. They are as follows:

a) official refusal to recognize financial liabilities;

b) payment termination due to default;

c) operations shutdown due to technical failure

d) transaction terms changes;

e) monetary obligations waiver due to some objective circumstances such as currency restrictions in the country of a debtor. 
TABLE I. The main types of risks in international monetary and financial relations

\begin{tabular}{|c|c|}
\hline Types of risk & Specifications \\
\hline Sovereign risk & $\begin{array}{l}\text { This type of risk occurs when the state is not able to } \\
\text { fulfill its obligations to international partners, for } \\
\text { example, in case of currency, credit, stock and } \\
\text { insurance operations }\end{array}$ \\
\hline Political risk & $\begin{array}{l}\text { This type of risk involves the probability of losses if } \\
\text { the state fails to fulfill its international obligations to } \\
\text { banks, corporations (legal entities) due to the } \\
\text { deterioration of the economic or political situation } \\
\text { in that country (aka embargo) }\end{array}$ \\
\hline Strategic risk & $\begin{array}{l}\text { This type of risk occurs as a result of a wrong or } \\
\text { mistakenly chosen strategy by one of the } \\
\text { counterparties, i.e. incorrectly chosen instruments or } \\
\text { forms of international settlements and falsely } \\
\text { predicted estimates or a business plan, etc. }\end{array}$ \\
\hline Market risk & $\begin{array}{l}\text { It results from condition changes in the financial } \\
\text { market, i.e. the ratio change of supply and demand, } \\
\text { transaction prices or the goods supply }\end{array}$ \\
\hline Systemic risk & It features the cyclical development of the economy \\
\hline Legal risk & $\begin{array}{l}\text { This type of risk is connected with the unforeseen } \\
\text { changes in the legislation of the foreign } \\
\text { counterparty's country. If the national legal norms } \\
\text { contradict international rules, it may inflict losses }\end{array}$ \\
\hline Reputational risk & $\begin{array}{l}\text { A participant's rating decrease, who is involved in } \\
\text { international relations. Also, country's credit rating } \\
\text { deterioration }\end{array}$ \\
\hline Operational risk & $\begin{array}{l}\text { Technique violation of conducting operations in the } \\
\text { financial market, i.e. incorrectly introduced data or } \\
\text { amount }\end{array}$ \\
\hline Technological risk & $\begin{array}{l}\text { The loss risk due to e-banking, which might imply } \\
\text { some attempts to break the system, crash or the } \\
\text { breakdown of data transmission equipment. }\end{array}$ \\
\hline Liquidity loss risk & $\begin{array}{l}\text { This type of risk is connected with a participant's } \\
\text { solvency decrease or their financial status } \\
\text { deterioration }\end{array}$ \\
\hline
\end{tabular}

Market risk could be divided into an interest risk, currency and stock risks. Unfortunately, the cases of Internet fraud and hacking of personal accounts in international settlements have become more frequent. So, it is quite evident that the technological risk requires special attention. Also, economic security measures need to be implemented.

\section{CURRENCY RISK, CREDIT AND TRANSFER RISKS}

First of all, any type of risk depends on the conditions of a particular transaction or international operation. The basis of the currency risk is the financial asset value change at a particular time. A participant of international relations may undergo some financial losses if the contract price decreases due to the currency exchange rate. Unfortunately, the price, which is specified in the contract, depends heavily on the exchange rate. It happens because it indicates the payment price. The transaction could be a total failure due to the fact that the exporter receives a lower payment than previously declared. Naturally, such outcome does not depend on the will of participants; quite the opposite, all counterparties can potentially suffer from losses, e.g. an importer may well suffer from revaluation.

Importers and debtors face the currency risks, if the currency rate price rises in comparison with the payment currency. In both cases, the debtor's national currency equivalent will always be less than the sum having been agreed on earlier. Exchange rate fluctuations lead to some banks and companies going bankrupt. On the other hand, this could be highly beneficial to some other banks and companies. However, foreign exchange risks might badly affect both public and private owners of foreign currency.

Credit risk is when the borrower fails to pay the loan and interest; interest rate risk arises as a result of an interest rate change stipulated by the terms of the international contract, in a time period of drawing the contract up and its compliance. In this case, the creditor will keep on incurring losses if the interest rate rises (compared to the rate specified in the contract), and the borrower if the interest rate decreases.

In addition, there is a risk of the loan cost increase, i.e. commission overcharging; some hidden contractual elements such as compulsory insurance, loan collateral and the requirement to open a deposit under unfavorable conditions for the borrower. Such conditions place the debtor at a disadvantage; seeing this, the debtor should be able to protect their rights while making the loan agreement or any other type of international contract.

Transfer risk may occur due to restrictions or default in the borrowing country; and as a result, the debtor's failure to pay off the debt.

\section{RISK ASSESSMENT METHODS}

The choice of methods is an important aspect of the risk management system. The risk management system can be understood as a set of tools and methods used to reduce perceived hazards and losses as a result of an adverse outcome.

The world practice shows an integrated approach to the risk management system. This very approach is not only about identifying and diversifying risks, but it is also about the ability to identify risks promptly and take appropriate measures to minimize or eliminate them.

Taking into account the peculiarities of the operations being conducted, there is a risk management model which includes the following stages:

- $\quad$ risk management purpose definition;

- $\quad$ risk assessment and analysis;

- measures to reduce risks.

Each stage contains relevant activities and the final action is the result analysis and activities assessment. It is important to determine risk management objectives early, also to identify all possible risk situations and give an objective assessment of each possible type of risk. Then, to carry out an in-depth analysis of risks in international monetary and financial transactions; to assess them and take measures to eliminate them such as risk reduction, risk transfer, risk evasion and taking risks. 
There is a large number of different risk management methods in international monetary and financial relations [9].

Table II displays the main risk assessment methods in international operations.

TABLE II. Operations risk assessment methods in the global financial market

\begin{tabular}{|l|l|}
\hline \multicolumn{1}{|c|}{ Method name } & \multicolumn{1}{|c|}{ Specifications } \\
\hline VaR (Value at Risk) & $\begin{array}{l}\text { Possible losses estimation with a } \\
\text { predetermined time factor }\end{array}$ \\
\hline $\begin{array}{l}\text { SPAR (the Standard } \\
\text { Portfolio Analysis of Risk) }\end{array}$ & Standard risk portfolio assessment \\
\hline Shortfall & $\begin{array}{l}\text { The use of capital reserves as a } \\
\text { conservative risk assessment method }\end{array}$ \\
\hline
\end{tabular}

The Value at Risk method is the most popular amongst all the presented risk management options. This method has been used in the world practice since the mid 1990s and it allows one to assess the average operations risks in different global financial market sectors and to aggregate the risk.

Let us assume that the daily value of $\mathrm{VaR}$ is 2 million euros with a probability of $95 \%$, and then the possible losses will not exceed the amount of 2 million euros with a probability of $95 \%$.

The use of this method allows the international transactions participants to insure themselves against possible losses by creating reserves for possible losses; also, it allows one to determine the loss limit due to exchange rate fluctuations; and to plot the exchange rate changes and to determine critical fluctuation points within certain values.

If the circumstances are favorable, the exchange rate changes create reserves every day; the chart critical points will shift to the established limits. The exchange rate analysis and its dynamics naturally lead to currency insuring, in case the reserves of exchange rate fluctuations and the loss limit have been settled. Also, the bases of the statistics given determine the critical points coefficients, i.e. the upper and lower limits of the currency position. In addition to plotting, the VaR method uses the stress testing and the crisis situation modeling.

The SPAR method, which is based on portfolio theories, is used to assess the risk of portfolio securities, investments and debts in foreign and financial assets in order to reduce possible losses and calculate the liquidity safety guarantees with regard to the components specifics.

This management method is applied to specific financial assets and in certain conditions.

The listed methods of risk management in international monetary and financial relations are of a general nature and are used together with various methods of insurance.

\section{RISKS INSURANCE}

The idea of insuring against unforeseen situations or economic losses hit the participants in international monetary and financial relations at the very beginning of the world trade formation and development. However, the insurance procedure received a more professional look after the Second
World War in the form of defense reservations in international operations.

There are several types of defense reservations [10]:

- $\quad$ gold; direct; indirect reservations;

- $\quad$ currency; multicurrency; single-currency reservations;

- commodity-price reservation; flexible price reservations; index clauses;

- combined commodity and currency reservation.

During the period of the gold standard and gold value, the main payment unit was gold, so it is relevant to have and use the gold clauses as a way of insurance for international transactions.

The golden clause is the method of insurance against financial risks, based on the fixed gold value of the payment currency at the time of the contract execution. And it is suggested to recalculate the payment amount in proportion to the gold value change directly on the date of the international contract execution.

There are direct and indirect gold clauses in the structure of gold clauses. The direct gold clause means that the amount of all counterparts' obligations was equal to the amount of gold, and the indirect gold clause means that the amount of obligations was recalculated into currency, and the amount of payment was changed (increased in proportion to the gold value decrease and vice versa). Of course, the use of gold clauses was not always convenient, acceptable and even possible. So in some countries there was a ban on the use of gold clauses and as a result of violent fluctuations in the gold market price this way of insurance against currency risks was forgotten.

Currency clauses have replaced the gold clauses. Currency clauses provide the revision of the payment amount in proportion to the change in the exchange rate for the purposes of insurance of the interests of the importer and exporter. In this option, there is a currency of exchange clause (for example, the US dollar) and the payment currency (Canadian dollar). During the decline in the dollar, the exporter and the importer of the transaction will suffer losses from currency depreciation. The recalculation of the payment amount upon the implementation of the currency clauses is made in proportion to the change in the exchange rate of the currency of exchange clause (or currency of the price) in relation to the payment currency.

Currency clauses can be divided into single-currency and multi-currency. Multi-currency clauses provide the change of the payment amount of the international contract, depending on the change in the basket of currencies, which act as a stable contract price. Advantages of this method of insurance against currency risks are the following: 
- the application of the currency basket allows one to reduce the probability of a violent fluctuation in the exchange rate of several currencies in connection with the devaluation and, thereby, the probability of change of the payment amount is reduced;

- the method ensures compliance with the financial interests of counterparts of the international transaction, because the choice of currencies included in the basket depends on them and thereby the currency risk is reduced.

The effectiveness of the insurance procedure largely depends on the quality of the selected currencies in the basket, as a rule, the most stable currencies or international monetary units are selected. Also in the world practice, there are several options for forming a currency basket, such as:

- a symmetrical basket (all currencies have an equal specific weight);

- an asymmetrical basket (different specific weights of currencies);

- a standard basket (the specific weight of the currencies is fixed at the moment of application of the currency unit as the currency of exchange clause)

- controlled basket (possible change under the influence of market factors).

According to the international statistics, the use of multicurrency protection clauses in SDRs (special drawing rights) and ECUs (European currency units) prevails in international transactions, sometimes an option price is used (the choice of the payment currency in several currencies is provided and then, upon the contract execution date, the exporter has the right to choose).

Defense reservations are examples of classic insurance for participants in international transactions against foreign exchange, credit and inflation risks [11]. The use of protective clausesis a way of insuring the counterparties against the onset of adverse events; but it does not provide the opportunity to obtain additional benefits.

The development of international relations and the world stock market have provoked new methods of financial risks insurance to appear, aka 'hedging'.Hedging involves insurance against adverse economic situations by creating counter claims in the stock market. Active services promotion in the field of currency risks hedging is crucial[12].

To insure the currency risk, the following options are used:

- Currency options;

- SWAP;

- $\quad$ Forward contracts;

- Futures contracts.

\section{A.CURRENCY OPTIONS}

Currency options are applied to insure against price changes. Options give the right to its owner (aka the holder of the option) to sell or buy a financial asset for a set price at a fixed time period. The currency option could be of various types.

A more detailed classification of options is presented in Table III.

TABLE III. Classification of currency options

\begin{tabular}{|c|c|c|}
\hline Criterion & Classification & Comment \\
\hline $\begin{array}{l}\text { Depending on } \\
\text { future actions } \\
\text { with the option }\end{array}$ & $\begin{array}{l}\text { - purchase option (call } \\
\text { option); } \\
\text { - sale option (put option) }\end{array}$ & $\begin{array}{l}\text { The put option is } \\
\text { acquired for further } \\
\text { selling of the asset at the } \\
\text { certain price and at the } \\
\text { certain time. The call } \\
\text { option is acquired to } \\
\text { purchase a specific } \\
\text { asset. }\end{array}$ \\
\hline $\begin{array}{l}\text { Depending on } \\
\text { the basic asset } \\
\text { market }\end{array}$ & $\begin{array}{l}\text { - currency; } \\
\text { - stock; } \\
\text { - commodity; } \\
\text { - index option; } \\
\text { - options on physicals; } \\
\text { - interest rate option; } \\
\text { - option of futures contract }\end{array}$ & $\begin{array}{l}\text { The division of currency } \\
\text { options into subspecies } \\
\text { depends on one or } \\
\text { another basic asset, } \\
\text { which will be the subject } \\
\text { of contractual relations } \\
\text { between the transaction } \\
\text { parties. } \\
\text { The interest rate option } \\
\text { provides the value as the } \\
\text { base asset at which the } \\
\text { option can be purchased. } \\
\text { The options on physicals } \\
\text { defines security papers } \\
\text { with fixation of } \\
\text { profitability as an asset. }\end{array}$ \\
\hline $\begin{array}{l}\text { Complex types } \\
\text { of currency } \\
\text { options }\end{array}$ & $\begin{array}{l}\text { - barrier option; } \\
\text { - bargain purchase price } \\
\text { option; } \\
\text { - abandonment option; } \\
\text { - option with flexible } \\
\text { structure; } \\
\text { - option with a two-level } \\
\text { structure; } \\
\text { - postponement option; } \\
\text { - swaption; } \\
\text { - other }\end{array}$ & $\begin{array}{l}\text { These types of currency } \\
\text { options are more } \\
\text { difficult to use than their } \\
\text { usual types. However, } \\
\text { these types of options } \\
\text { contain more detailed } \\
\text { conditions for the } \\
\text { transaction execution } \\
\text { and allow one not only } \\
\text { to insure the interests, } \\
\text { but also to obtain certain } \\
\text { benefits. }\end{array}$ \\
\hline
\end{tabular}

The option purchase is used to insure the latent currency risk in license trading, sub-delivery negotiations or financing, i. e. the need for obligation or any other requirement depends on the offer acceptance by the counterpart.

In order to insure the currency risk, a 'straddle' operation is used. It is a combination of a call option and a put option for the same bond with the same exchange rate.

\section{B. SWAP}

SWAP is a derivative financial instrument used for hedging currency risks. The SWAP implies making a contract along with the asset's price being fixed; the asset should then be repurchased at the same fixed price [13].The swap is an example of a futures deal/time bargain. There are two types of it, i.e. the currency SWAP and the interest rate SWAP. Interest rate SWAP is used in the inter-bank loans market to insure the participants against interest rate changes [14]. 


\section{FORWARD AND FUTURES CONTRACTS}

The futures contract is defined as an exchange-traded contract, while the forward contract is an over-the-counter one. Generally, these contracts are to supply goods or assets in the future under pre-arranged terms and conditions [15]. The differences between the futures contract and the forward contract are displayed in the table presented below.

TABLE IV. Comparative analysis of forward and futures contracts

\begin{tabular}{|l|l|l|}
\hline \multicolumn{1}{|c|}{ Specifications } & \multicolumn{1}{|c|}{ Futures (contract) } & \multicolumn{1}{|c|}{ Forward (contract) } \\
\hline $\begin{array}{l}\text { Assets covered by } \\
\text { contract }\end{array}$ & $\begin{array}{l}\text { Established by stock } \\
\text { exchange }\end{array}$ & $\begin{array}{l}\text { Depends on a buyer's } \\
\text { needs; may vary }\end{array}$ \\
\hline Asset quality & Set by stock exchange & $\begin{array}{l}\text { Depends on consumer's } \\
\text { desire and ability }\end{array}$ \\
\hline Delivery date & $\begin{array}{l}\text { Only on days set by } \\
\text { stock exchange }\end{array}$ & Not specified \\
\hline Liquidity & $\begin{array}{l}\text { Could be quite high; } \\
\text { depends on the type of } \\
\text { basic asset }\end{array}$ & Limited \\
\hline Risk & $\begin{array}{l}\text { Minimized; transaction } \\
\text { support by stock } \\
\text { exchange }\end{array}$ & High risk level \\
\hline Adjustability & $\begin{array}{l}\text { Contractual relations } \\
\text { regulated by stock } \\
\text { exchange }\end{array}$ & $\begin{array}{l}\text { Regulations minimized, } \\
\text { only according to the } \\
\text { current legislation }\end{array}$ \\
\hline Margin & Commission fee & Absent or minimal \\
\hline
\end{tabular}

The futures contract and the forward contract are quite similar and give an opportunity not only to insure one's rights but also to get a certain benefit when putting the money in the stock market. Still, the futures contract provides a greater guarantee to insure one's interests and minimize the currency risks. However, the cost could be quite high, which in its turn allows the over-the-counter one to develop freely.

It is worth saying that any hedging tool has its own advantages and disadvantages. A more detailed description of the hedging instruments is displayed in the table presented below.

TABLE V. Financial hedging instruments assessment

\begin{tabular}{|l|l|l|}
\hline \multicolumn{1}{|c|}{ Method name } & \multicolumn{1}{|c|}{ Benefits } & \multicolumn{1}{c|}{ Shortfalls } \\
exchange & $\begin{array}{l}\text { Manages currency risk } \\
\text { and allows to receive an } \\
\text { income as a result of } \\
\text { basic asset price change }\end{array}$ & $\begin{array}{l}\text { Currency options are highly } \\
\text { priced, since a premium } \\
\text { needs to be paid out for } \\
\text { using the option. The option } \\
\text { may not always correspond } \\
\text { to the individual } \\
\text { requirements of the option } \\
\text { holder }\end{array}$ \\
\hline SWAP & $\begin{array}{l}\text { Allows you to insure } \\
\text { currency risks for a long } \\
\text { time period. By using }\end{array}$ & $\begin{array}{l}\text { Short-term contracts could } \\
\text { not be made }\end{array}$ \\
$\begin{array}{l}\text { SWAPS, a currency } \\
\text { portfolio could be built } \\
\text { and manage currency } \\
\text { positions could be } \\
\text { managed }\end{array}$ & $\begin{array}{l}\text { Most common type of } \\
\text { risk insurance; based on } \\
\text { standard stock exchange } \\
\text { contracts. All risks are } \\
\text { taken by stock exchange. } \\
\text { The futures contract is } \\
\text { low priced for opening a } \\
\text { position, time and high }\end{array}$ & $\begin{array}{l}\text { High commission costs; } \\
\text { inability to participate in a } \\
\text { transaction preparation } \\
\text { terms }\end{array}$ \\
\hline Futures contract
\end{tabular}

\begin{tabular}{|c|c|c|}
\hline & liquidity & \\
\hline Forward contract & $\begin{array}{l}\text { Direct participation in } \\
\text { contract } \\
\text { Transactions can be } \\
\text { made in any currency } \\
\text { and for different time } \\
\text { periods }\end{array}$ & $\begin{array}{l}\text { Low liquidity. Contract } \\
\text { termination impossible } \\
\text { before it expires. Highly- } \\
\text { risked implementation of } \\
\text { the forward contract }\end{array}$ \\
\hline
\end{tabular}

The financial instruments presented above are widely used for currency risk hedging. The implementation of each instrument depends on various factors, conditions and features of the stock market. Currency SWAPS tend to develop actively, as they allow one to build foreign currency portfolios for protection against foreign currency exchange rate depreciation. However, the futures contracts are equal to SWAPS in their popularity; they are actively used for hedging purposes, and in some cases for the stock market speculation.

\section{VIII.CONCLUSION}

All in all, it could be noted that today there are many types of risks as well as various insurance methods. However, when choosing the method of insurance in international currency and credit operations, it is necessary to focus on the conditions of the country's financial market as well as other microeconomic and macroeconomic factors.

\section{References}

[1] O.N. Pakova, E.V. Poberezhnaya, K.I. Nekhorosheva, "International monetary and credit relations in Russia: problems and solutions", Ekonomika i upravlenie: problemy, resheniya, vol. 12, pp. 28-32, December 2016.

[2] S.A. Lukyanov, E.G. Knyazev [et al.] International currency and credit relations, Ekaterinburg: Publishing house Ural. University, 2015, p. 296.

[3] A.K. Bondarev, S.M. Drozdov, A.I. Evdokimov, International economic relations, Moscow: Prospectus, 2014, p. 655.

[4] Oxford dictionary, Euromarket word meaning [An electronic resource]. https://en.oxforddictionaries.com/definition/

[5] B.A. Rayzberg, Modern economic dictionary [An electronic resource] Access mode: http://www.consultant.ru.

[6] Yu.A. Konoplyova, "The characteristic of securities as financial phenomenon in economic sphere", Terra Economicus, vol. 2-3, pp. 3335, March 2011.

[7] G.L. Avagyan, Yu.G. Veshkin International currency and credit relations. - Moscow: Magistr, Infra-M, 2012, p. 704.

[8] A.R. Khasanova, Yu.N. D'akova. "Review of methods of the analysis and management of financial risks", Ekonomika i upravlenie: problemy, resheniya, vol. 9, pp. 204-208, September 2016.

[9] B.V. Srebnik, T.B. Vilkova, Financial markets: professional activity on financial market, Moscow: Infra-M, p. 365, 2012.

[10] Terminological dictionary of bank and financial terms [An electronic resource]. -http://dic.academic.ru/dic.nsf/

[11] N.I. Berzon, D.M. Kasatkin, A. Y. Arshavsky, etc., Securities Market, Moscow: Yurayt, p. 531, 2011.

[12] N.N. Kunitsyna, E.V.Sitnikova "Currency Risks Hedging of Commercial Banks' Corporate Clients", Journal of Internet Banking and Commerce, vol. 21,2016

[13] Official site of the International Monetary Fund [An electronic resource]. -http://www.imf.org/external/index.htm.

[14] Official site of the Central bank of the Russian Federation (Bank of Russia) [An electronic resource]. -http://www.cbr.ru.

[15] Official site of the Moscow exchange. -http://www.micex.com. 